\title{
A Novel wideband VHF antenna for impulse GPR applications
}

- Dong Tan Phuoc

- Bui Huu Phu

DCSELAB, University of Technology, VNU-HCM

- Pham Minh Quang

Post and Telecommunications Institute of Technology

(Manuscript Received on December $11^{\text {th }}, 2013$; Manuscript Revised September 05 ${ }^{\text {th }}$, 2014)

\section{ABSTRACT:}

A novel wideband VHF antenna for the impulse ground penetrating radar (GPR) system at $200 \mathrm{MHz}$ central frequency is presented in this article. The antenna improves the impulse GPR system for increasing ability penetration. By using the Lemniscate curve, this novel structure of the proposed antenna achieve better radiation than other bow-tie proposes the UWB balanced-to-balanced (balun) transformation line is designed to feed the antenna. The balun is an important element for improving the bandwidth of the antenna. The fabrication of the antenna is only simple but also low cost with FR4 substrate and copper patch. The proposed antenna is designed and antennas. In addition, this article also fabricated with the successful results.

Keywords: Impulse ground penetrating radar (GPR) system, Lemniscate curve, balanced-tounbalanced (balun), bow-tie antenna, Novel wideband VHF antenna.

\section{INTRODUCTION}

Ground penetrating radar (GPR) is sometimes called georadar, ground probing radar, or subsurface radar. GPR uses electromagnetic wave propagation and scattering to image, locate and quantitatively identify contrasts in electrical and magnetic properties in the ground. [1] Detectability

of a subsurface feature depends upon contrast in electrical and magnetic properties, and the geometric relationship with the antenna.
Quantitative interpretation through modeling can derive from ground penetrating radar data such information as depth, orientation, size and shape of buried objects, density and water content of soils, and much more. Important component in any GPR system are the transmitter and receiver antennas [2]. Antennas radiate electromagnetic energy in the microwave band (UHF/VHF frequencies) when there is a change in the acceleration of the current on the antenna. Antennas also convert electromagnetic waves to currents on an antenna 
element, acting as a receiver of the electromagnetic radiation by capturing part of the electromagnetic wave [3].

The depth range of GPR system depends on not only the electrical conductivity of the ground but also the transmitted central frequency. The lower frequency will make the deeper penetration. So, the GPR systems requite the designed antenna that has a low central frequency in VHF range. Recently, there are many researches for improving the deeper penetration of the impulse GPR system. The antenna is situated above dry sand with relative dielectric permittivity in the $500 \mathrm{MHz}-3$ $\mathrm{GHz}$ range and with very small conductivity [4]. The antenna has a broadband and makes the GPR system to high resolution. However, the UHF central frequencies of this antenna don't improve the range of depth for the impulse GPR system. Besides, ZOU Aimin, LI Jicai, WANG Keke and CHENG Defu have experimental results show that voltage standing wave ratio (VSWR) of the loaded antenna is less than 2.5 in the band $0-300 \mathrm{MHz}$ [5]. However, the value of VSWR make performance of the antenna is not good and it is the trouble for processing signals in the receiver. In addition, Chen Guo and Richard C.Liu provided Shielded antenna system [6]. Although they make a good Transmitting signal with shielding and absorbing materials, their designed antenna is used in a GPR system working at $400 \mathrm{MHz}$ central frequency.

In this article, we propose a novel wideband VHF antenna to improve the deep penetration for the impulse GPR system. Unlike the above bow- ties antenna in [5], [6] and [7], the antenna is based on Lemniscate curve to achieve a good radiation. The proposed balun has a broadband and makes a good matching impedance. The dimension of the antenna is smaller than other bow-tie antennas at the same central frequency. The antenna is successfully optimized by CST MICROWAVE STUDIO software. The proposed antenna has the return loss is less than $-10 \mathrm{~dB}$ and VSWR is less than 2 in band 176-232 MHz. The results show good agreement between simulation and measurement.

\section{THE PROPOSED LEMNISCATE ANTENNA}

The proposed antenna has FR4 dielectric substrate and copper patch for the impulse GPR system. We use the Lemniscate cure to create the structure of the antenna. This curve of the patch of antenna is shown in Figure 1. The locus of the point $\mathrm{P}$ on the Lemniscate curve can be determined from two focal points $F$ and $F$ ' such that $2 \mathrm{OF} \mathrm{OF}^{\prime}=\mathrm{a} 2$ (where $\mathrm{a}$ is the distance from $\mathrm{O}$ to the center focal point $F$ ). The equation of Lemniscate curve in Cartesean coordinate is shown [7]:

$\left(x^{2}+y^{2}\right)^{2}-2 a^{2}\left(\mathrm{x}^{2}-\mathrm{y}^{2}\right)=0$

And the form in plolar coordinate is shown:

$r^{2}=2 a^{2} \cos (2 \theta)$

The curve Lemniscate of the proposed antenna has length $\mathrm{La}=541.3 \mathrm{~mm}$, width $\mathrm{Wa}=182 \mathrm{~mm}$, and the gap between the two wings of the antenna is $5 \mathrm{~mm}$, as shown in Figure 2. 


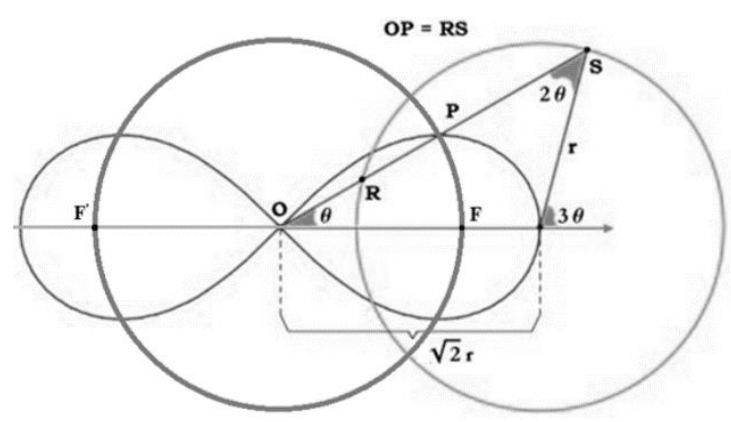

Fig 1. The Lemniscate curve

The curve Lemniscate of the proposed antenna and the gap between the two wings of the antenna has length $\mathrm{La}=541.3 \mathrm{~mm}$, width $\mathrm{Wa}=182 \mathrm{~mm}, \quad$ is $5 \mathrm{~mm}$, as shown in Figure 2.

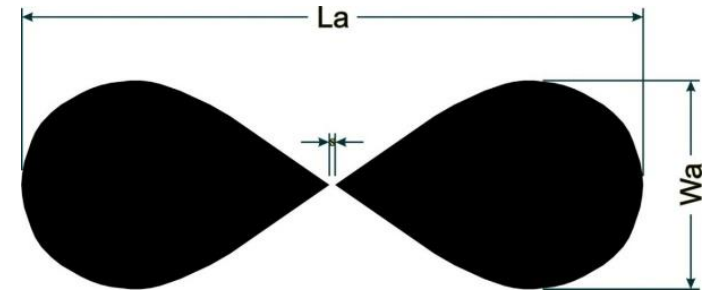

Fig 2. Geometry and configuration of the proposed antenna

The distance of Lemniscate curve for this antenna is $\sqrt{2} r=268.15 \mathrm{~mm}$ and $\mathrm{OF}=186.61$ $\mathrm{mm}$. Like the dipole antenna, the feed line of Lemniscate antenna is located in middle of the wings at $\mathrm{S}$ opened point. The proposed antenna uses FR4 dielectric material which has a length Ls

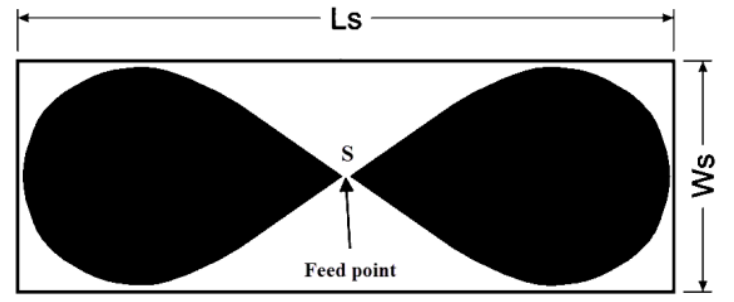

Fig 3.Geometry and configuration of the proposed antenna is based on substrate with feed point

The microstrip taper balun is designed to transform from the unbalanced structure of the coaxial cable $50 \Omega$ impedance to the antenna
$=546.3 \mathrm{~mm}$, width $\mathrm{Ws}=192 \mathrm{~mm}$, the thickness of FR4 dielectric substrate $\mathrm{h}=1.6 \mathrm{~mm}$, dielectric constant $\varepsilon r=4.6$, loss tangent $\tan \delta=0.02$, and the thickness of the copper patch $\mathrm{t}=35$ micrometers, shown in Figure 3.

\section{Trang 50}


the antenna impedance to $50 \mathrm{Ohm}$ and a portion which actually performs the mode transduction.

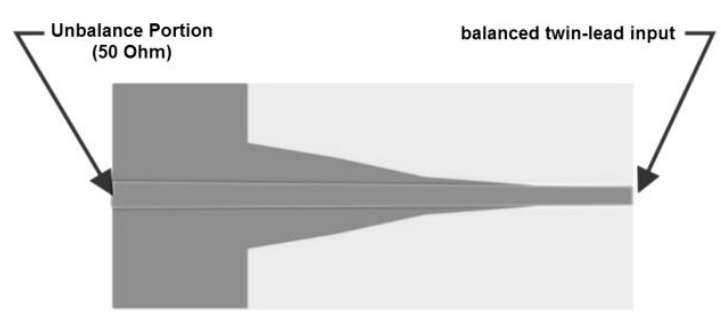

Fig 4. Configuration of the microstip taper balun
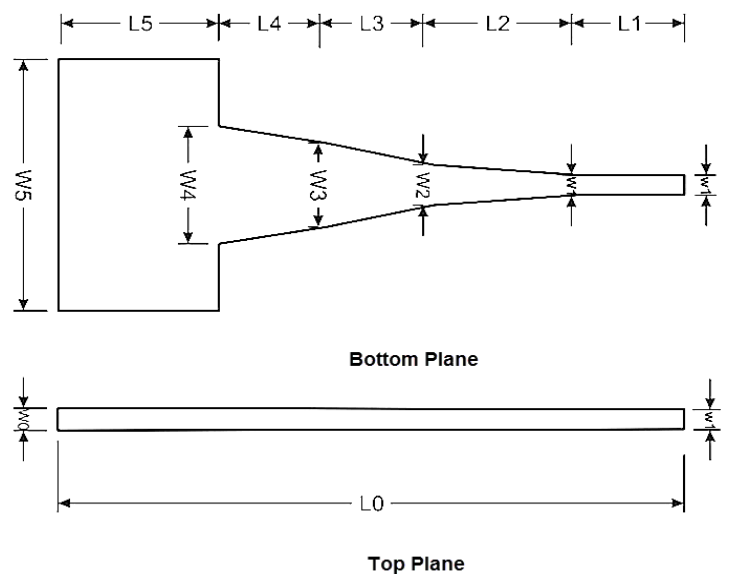

Fig 5. The dimensions of balun

Table 1. The dimension values of balun

\begin{tabular}{|c|c|c|}
\hline $\mathrm{n}$ & Wn $(\mathrm{mm})$ & Ln $(\mathrm{mm})$ \\
\hline 0 & 3 & 300 \\
\hline 1 & 3 & 60 \\
\hline 2 & 6 & 90 \\
\hline 3 & 12 & 60 \\
\hline 4 & 25 & 60 \\
\hline 5 & 40 & 30 \\
\hline
\end{tabular}

We firstly simulate the antenna without balun. impedance of the antenna $\mathrm{Z}=42.52+3.24 * \mathrm{j}$ Ohm The value of reflection coefficient $\mathrm{S} 11=-21.1$ dB. S11 is less than $-10 \mathrm{~dB}$ and VSWR is less than 2 in the frequency range from $221.6 \mathrm{MHz}$ to at frequency $200 \mathrm{MHz}$. The real part and the imaginary part of the impedance respectively are presented in Figures 8 and 9.

184.38 MHz, as shown in Figures. 6 and 7. Input 


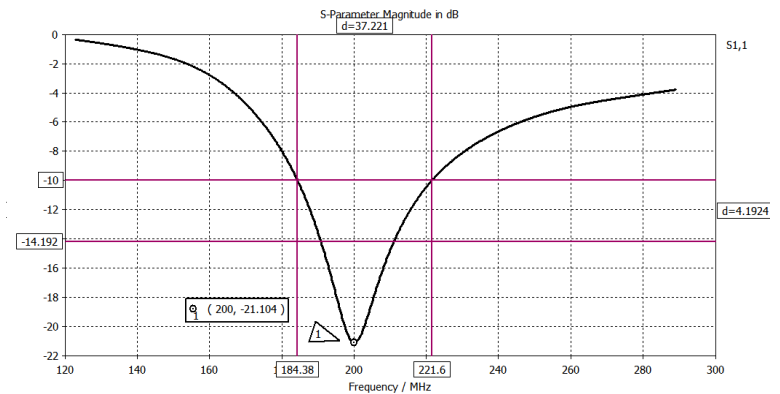

Fig 6.Return loss S11 of the antenna without balun

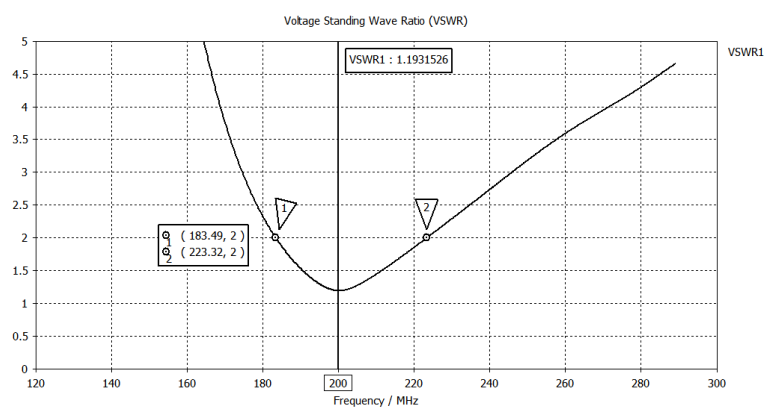

Fig 7. VSWR of the antenna without balun

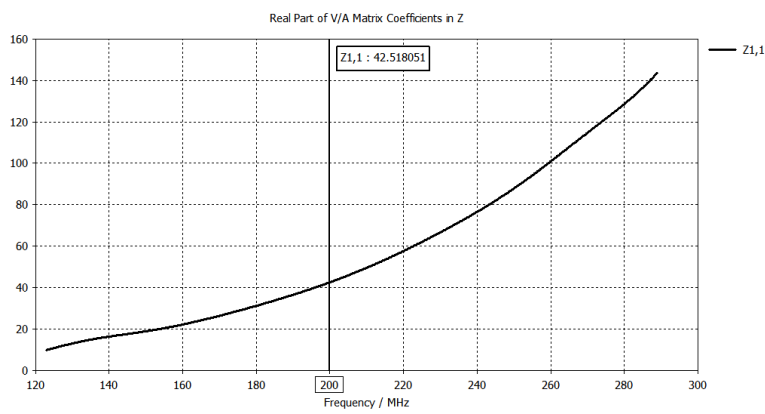

Fig8. The real part of the impedance

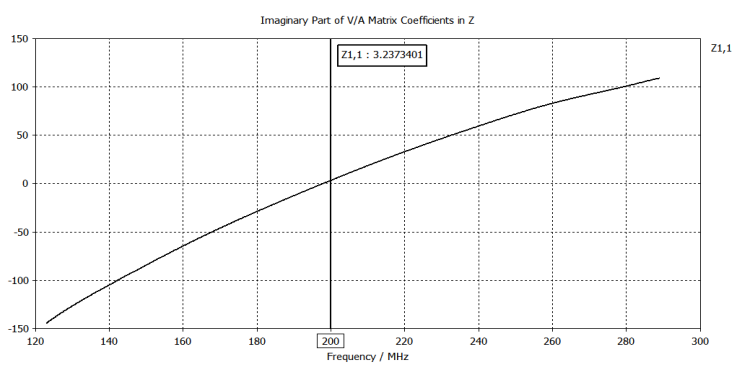

Fig 9. The imaginary part of the impedance

We use the balun to feed the antenna, make good match impedance and increase performance of antenna, is shown Figure 10. The simulation results of antenna with balun are show in Figures 11,12 , and 13 .

\section{Trang 52}




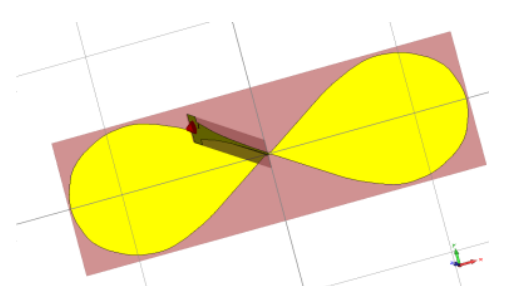

Fig 10. Antenna with balun in simulation environment of CST software

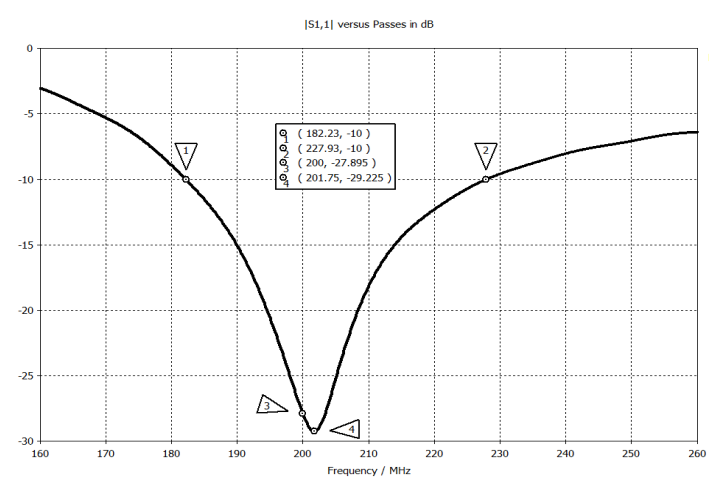

Fig 11. Return loss of antenna with balun

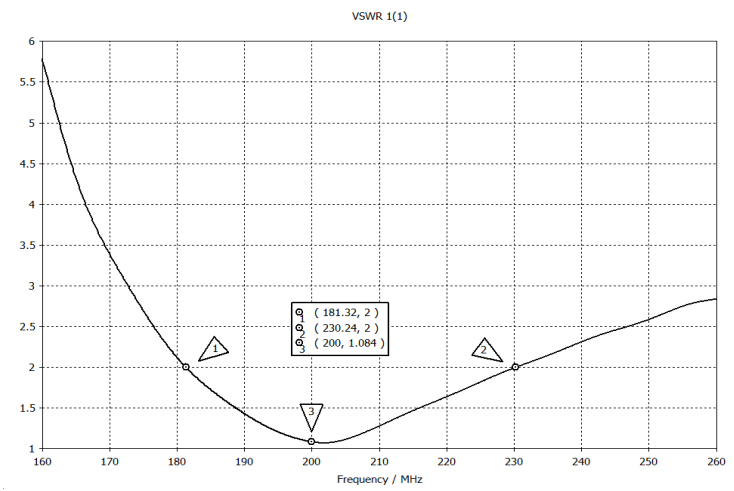

Fig 12. VSWR of the antenna with balun

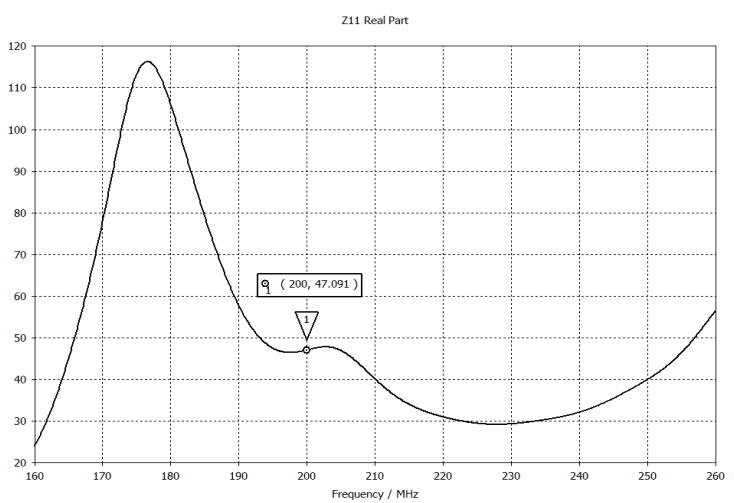

Fig 13. The real part of impedance in case the antenna with balun 


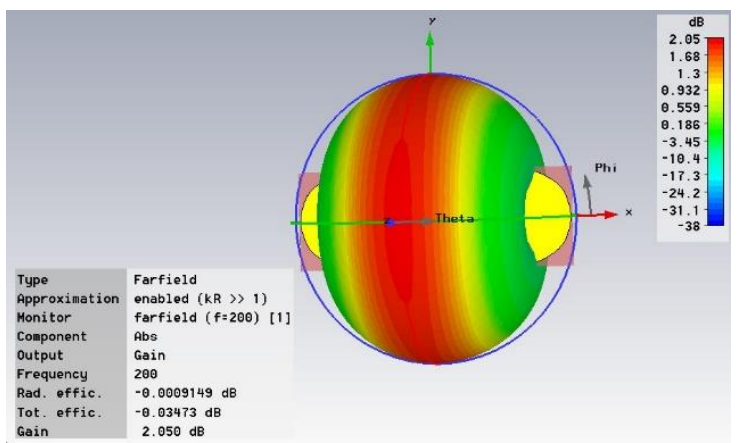

Fig 14. 3D radiation pattern of antenna at $200 \mathrm{MHz}$

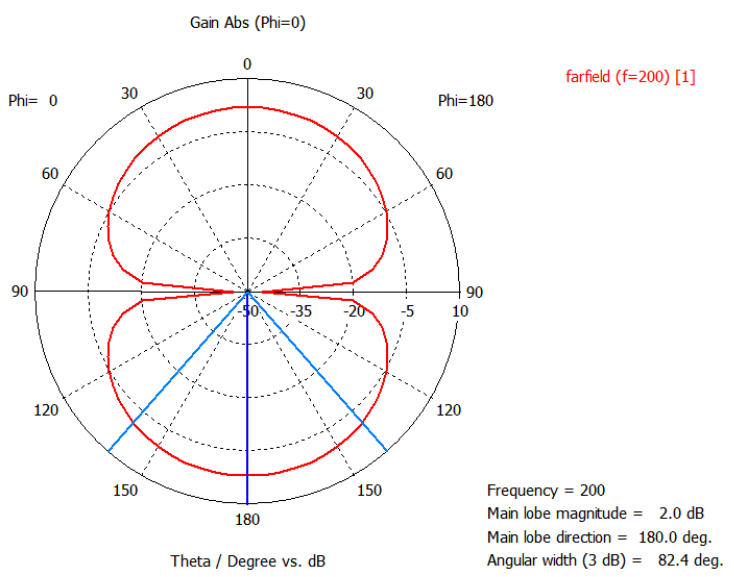

Fig 15. Radiation pattern of antenna at $200 \mathrm{MHz}$ in polar coo
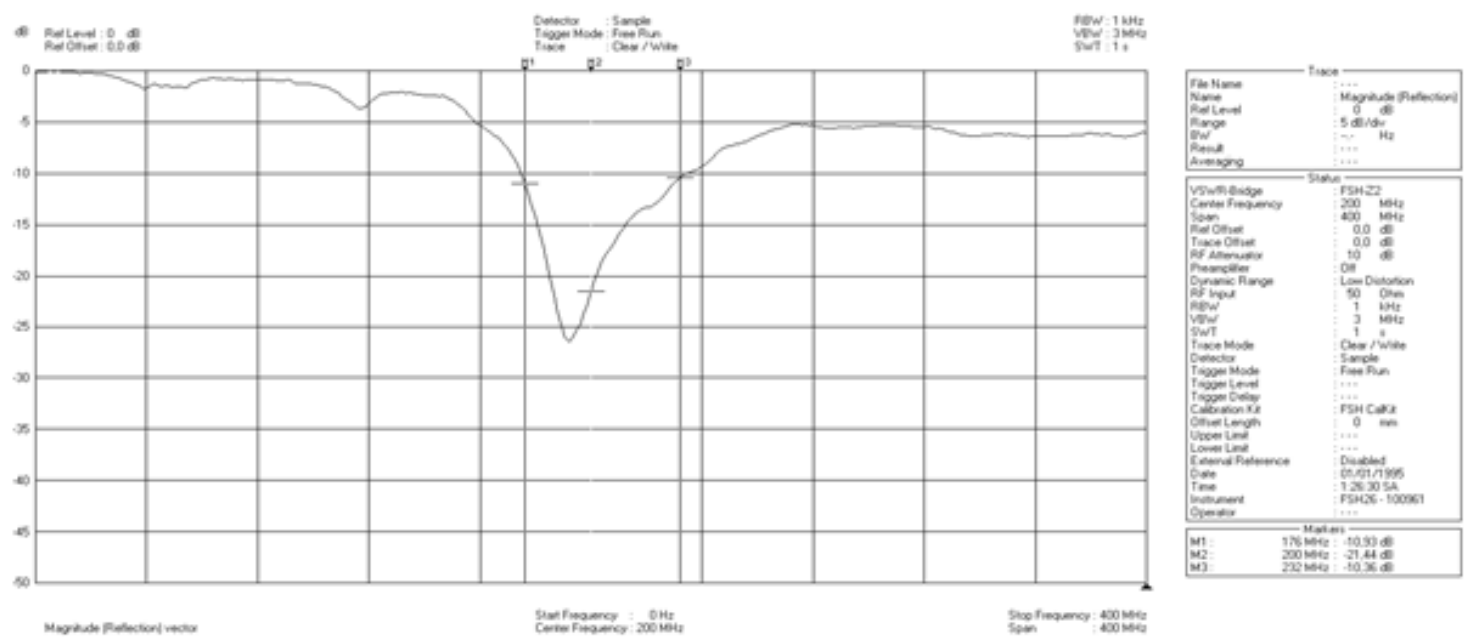

Fig 16. Measured reflection coefficient S11 


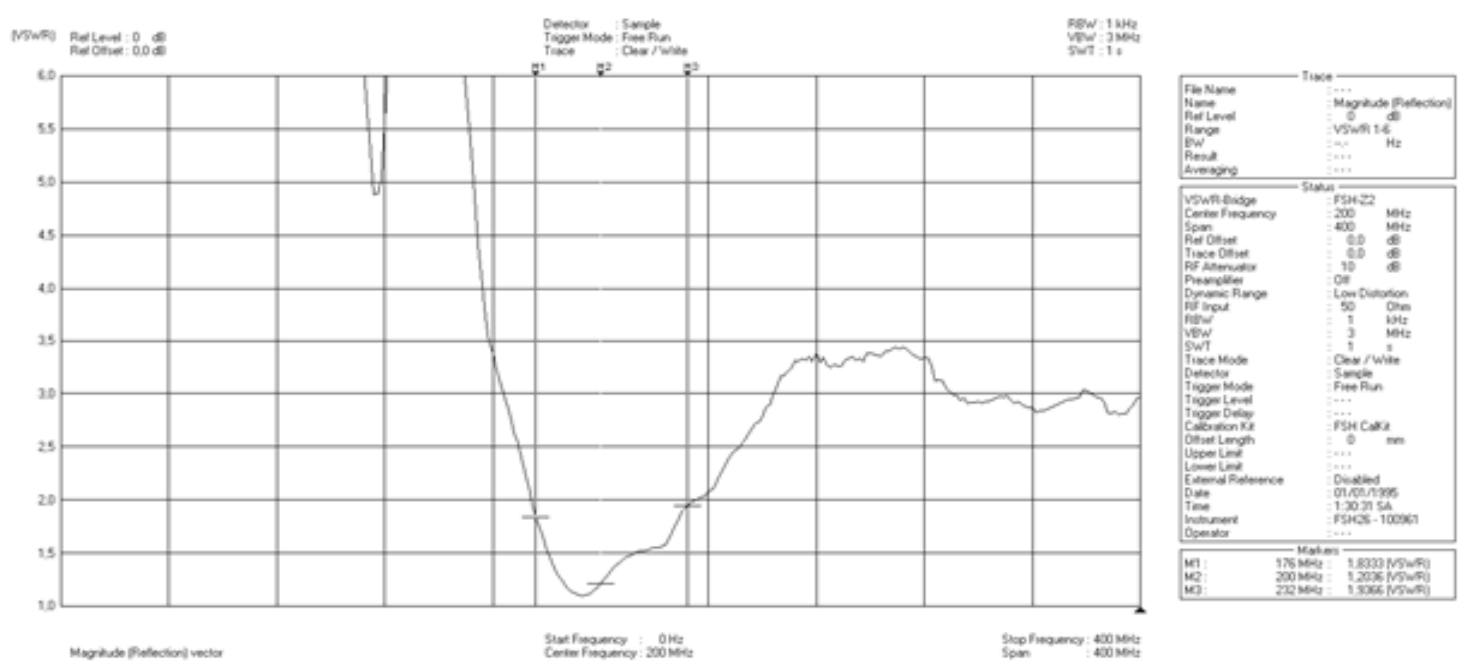

Fig 17. VSWR measurement

Reflevel : $0 \mathrm{~dB}$
Ref offset: $0,0 \mathrm{~dB}$

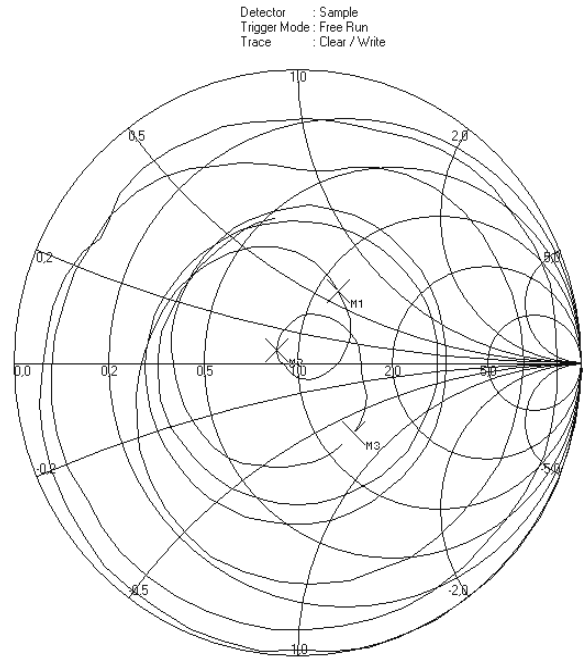

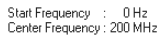

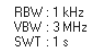

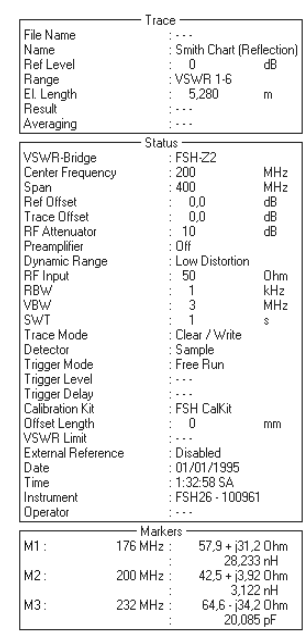

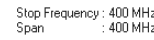

Fig 18. Smith Chart measurement

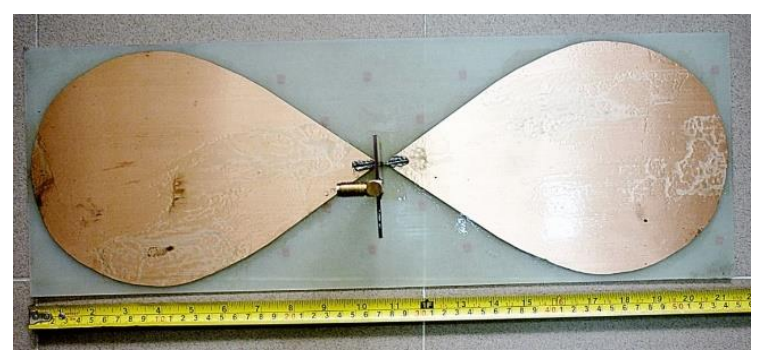

Fig 19. Geometry of the implemented antenna 
According to the above simulation results at the central frequency from Figure 11 to Figure 15, $\mathrm{S} 11$ is less than $-25 \mathrm{~dB}$ and the real part of the impedance is $47 \mathrm{Ohm}$. The bandwidth is $49 \mathrm{MHz}$, equivalent to $25 \%$ of the central frequency 200 MHz. The simulation results show that matching impedance in case of the antenna with the balun is better than the case of the antenna without the balun. So, the designed balun helps to increase the performance of antenna.

Radiation pattern in 3D and polar coordinate of the proposed antenna at $200 \mathrm{MHz}$ are shown in Figure 14 and 15, respectively. Radiation pattern focuses on two directions, which is suitable for applications need narrow beam width and GPR system is an example application. The low central frequency and the stability of radiation improve for the deeper penetration.

\section{EXPERIMENTAL RESULTS}

In this section, we present the measured results of the proposed antenna. The implemented antenna is shown in Figure 19. Figure 16 and 17 show the measured reflection coefficient S11 and VSWR with the wideband balun transformer line. The Smith Chart measurement of the proposed antenna is also shown in Figure 18. It proves that the antenna has a good matching impedance. The Table II and Table III compare the results of S11 and VSWR. The results of comparison show good agreement between simulation and measurement.

Table 2. Comparison results between simulation and measurement of S11

\begin{tabular}{|c|c|c|c|}
\hline Frequency $(\mathrm{MHz})$ & Simulated S11 $(\mathrm{dB})$ & Frequency $(\mathrm{MHz})$ & Measured S11 $(\mathrm{dB})$ \\
\hline 182.23 & -10 & 176 & -10.93 \\
\hline 200 & -27.9 & 200 & -21.44 \\
\hline 227.93 & -10 & 232 & -10.36 \\
\hline
\end{tabular}

Table 3.Comparison results between simulation and measurement of VSWR

\begin{tabular}{|c|c|c|c|}
\hline $\begin{array}{c}\text { Frequency } \\
(\mathrm{MHz})\end{array}$ & $\begin{array}{c}\text { Simulated } \\
\text { VSWR }\end{array}$ & $\begin{array}{c}\text { Frequency } \\
(\mathrm{MHz})\end{array}$ & $\begin{array}{c}\text { Measured } \\
\text { VSWR }\end{array}$ \\
\hline 181.32 & 2 & 176 & 1.833 \\
\hline 200 & 1.084 & 200 & 1.204 \\
\hline 230.24 & 2 & 232 & 1.972 \\
\hline
\end{tabular}

\section{CONCLUSIONS}

The novel wideband VHF antenna is successfully designed and measured for the impulse GPR system. The measured results show that the proposed antenna has a bandwidth from
176-232 $\mathrm{MHz}$, equivalent to $28 \%$ of the central frequency $200 \mathrm{MHz}$. The wideband balun makes a good matching impedance of the antenna. The structure of patch antenna is the Lemniscate curve. This structure is new way of designing antenna for 
the industrial production antennas. The implement of antenna is extremely low cost. Besides, the antenna is also suitable for other applications in VHF range. In future, the proposed antenna can be used to make an antenna arrays for the purpose of increasing performance and making a multichannel GPR system.

ACKNOWLEDGEMENT: This research is supported by National Key Laboratory of Digital Control and System Engineering (DCSELAB), HCMUT,

\section{Đề xuất một loại Anten băng rộng mới cho hệ thống radar xuyên đất dạng xung trong băng tần VHF}

- Đồng Tân Phước

- Phạm Minh Quang

- Bùi Hữu Phú

DCSELAB, Trường Đại học Bách Khoa, ĐHQG-HCM

\section{TÓM TÁT:}

Trong bài này, chúng tôi đưa ra một kiểu thiết kế mới cho anten băng rộng, ứng dụng cho hệ thống Radar xuyên đất (GPR) ở băng tần VHF. Với tần số trung tâm là $200 \mathrm{MHz}$, anten vi dải được thiết kế có thể đạt được độ xuyên sâu tối đa $5 \mathrm{~m}$ cho hệ thống Radar xuyên đất dạng xung. Anten được thiết kế theo kiểu anten bow-tie và kiến trúc được tạo theo dạng đường Lemniscate. Kiến trúc này giúp cho anten có được bức xạ tốt hơn so với các anten bow-tie hoạt động cùng tần số. Ngoài ra, một balun băng rộng được thiết kế để giúp anten phối hợp trở kháng tốt và tăng hiệu suất bức xạ. Việc thi công anten rất đơn giản và cực kỳ giảm chi chi phí với một lớp điện môi FR4 và một dải kim loại bằng đồng phía trên. Anten được mô phỏng, thiết kế và đo đạc thành công với sự phối hợp trở kháng tốt, độ lợi và sự bức xạ ổn định.

Từ khóa: Impulse ground penetrating radar (GPR) system, Lemniscate curve, balanced-tounbalanced (balun), bow-tie antenna, Novel wideband VHF antenna. 


\section{REFERENCES}

[1]. David J.Daniels (2004), Ground Penetrating Radar, The Institute of Electrical Engineers.

[2]. A.A. Pramudita, A. Kurniawan, and A. Bayu Suksmono, "Hexagonal monopole strip antenna with rectangular slot for 100 1000MHz SFCW GPR applications," International Journal of Antennas and Propagation, vol, 2008, pp.1-6.

[3]. A.G. Yarovoy, L.P. Ligthart, "Ultrawideband antennas for ground penetrating radar", International Research Centre for Telecommunications-transmission and Radar,Faculty of Information Technology and Systems, TU Delft, 2003.

[4]. A.A. Lestari, A.G. Yarovoy, L.P. Ligthart, "Adaptive wire bow-tie antenna for GPR applications", IEEE Trans, Antennas and Propagation, Vol. 53, 2005, pp. 174 - 1754.

[5]. Zou Aimin, Li Jicai, Wang Keke, Cheng Defu "Investigations of Rl-Loaded Bowtie Antenna for Low-Resolution GPR", Wireless Communications, Networking and Mobile Computing, 2009. WiCom '09. 5th International Conference on

[6]. Chen Guo, Richard C.Liu, "Design of a shielded antenna system for ground penetrating radar applications", IEEE Trans, Antennas and Propagation Society International Symposium, 2009, pp. 1- 4.

[7]. Fang Guangyou, Michele Pipan, "Designing of A Low Frequency Ultra-
WideBand (UWB) Antenna And Its Application In Ground Penetrating Radar(GPR) System”, Tenth International Cor@wnce on Ground Penetrating Radai; 21-24 June, 2004, Deljt, The Netherlands.

[8]. J. Dennis Lawrence (1972), A catalog of special plane curves, Dover Publications. pp. 4-5, 121-123, 145, 151, 184.

[9]. A.S. Turk, B. Sen (2003), "Ultra wide band antenna designs for ground penetrating impulse radar systems," IEEE EMC Symposium Records, Istanbul, Turkey.

[10]. Kiminami, K., A. Hirata, and T. Shiozawa (2004), "Double-sided printed bow-tie antenna for UWB communications," IEEE Antennas and Wireless Propagation Letters, Vol. 3, 152153.

[11]. Lestari, A. A., E. Bharata, A. B. Suksmono, A. Kurniawan, A. G. Yarovoy, and L. P. Ligthart (2010), “A modied bow-tie antenna for improved pulse radiation," IEEE Transactions on Antennas and Propagation, Vol. 58, No. 7, pp. 2184-2192.

[12]. Lestari, A.A. (2004), "RC-loaded bow-tie antenna for improved pulse radiation," IEEE Transactions on Antennas and Propagation, vol. 52, No. 10, pp. 25552563

[13]. P. Pramanick and P. Bhartia (1983), “Tapered Microstrip Transmission Line," 
IEEE MTT-S Int. Microwave Symp. Dig., pp. 242-244.

[14]. P. Pramanick and P. Bhartia (1987), "A Generalized Theory of Tapered Transmission Line Matching Transformers and Asymmetric Couplers Upporting Non-TEM Modes,” IEEE Trans.
Microwave Theory Tech., Volume 87, Issue 1, pp. $361-364$.

[15]. Romano, N., F. Soldovieri, and R. Persico (2010), "Design and numerical analysis of a new recongurable antenna for georadar applications," 13th International Conference on Ground Penetrating Radar, GPR 2010, 1-5, Jun. 21-25. 